\title{
A cell surface/plasma membrane antigen of Candida albicans
}

\author{
ReN-KaI Li and Jim E. CUTLER* \\ Department of Microbiology, Montana State University, Bozeman, MT 59717, USA
}

(Received 7 August 1990; revised 26 October 1990; accepted 14 November 1990)

\begin{abstract}
Antibody from BALB/cByJ mice immunized against a membranous fraction of Candida albicans agglutinated whole cells as well as the membranous fraction. Hybridoma techniques were used to isolate an IgM monoclonal antibody $(\mathrm{mAb})$ designated $10 \mathrm{G}$ which agglutinated whole cells and reacted with the subcellular fraction. Yeast cells of 15 additional $C$. albicans strains and isolates of $C$. stellatoidea, $C$. tropicalis, $C$. intermedia and $C$. lusitaniae were also agglutinated by $\mathrm{mAb}$ 10G. The antigen was not detected on other fungi, including Candida krusei, $C$. utilis, Cryptococcus neoformans, Cr. albidus, Torulopsis glabrata, Rhodotorula spp. and Saccharomyces cerevisiae. To determine the cellular location of the epitope to which $\mathbf{~ A b ~} 10 \mathrm{G}$ is specific, freeze-substitution was compared with traditional chemical fixation methods in preparation of samples for immunocolloidal gold electron microscopy (IEM). With both fixation procedures, the antigen recognized by mAb 10G was found randomly and densely concentrated on the plasma membrane on exponential-phase yeast-form cells and had a patchy distribution on the cell wall surface. Association of the antigen with the plasma membrane was confirmed by IEM of isolated membranes. On developing hyphal cells, antigen appeared first on the plasma membrane and later on the cell wall surface. Treatment of yeast cells with $\beta$-mercaptoethanol and Zymolyase before fixation removed the antigen from the surface but left the cytoplasmic antigen undisturbed. Treatment of yeast cells or solubilized antigen with heat or proteolytic enzymes (trypsin, Pronase B, proteinase $K$ ) did not remove or destroy the antigen, suggesting a nonprotein nature of the epitope.
\end{abstract}

\section{Introduction}

The cell wall and plasma membrane of Candida albicans constitute the barrier between its cytoplasm and the external environment. These layers are intimately involved in the shape of the cell, antigenicity and secretion of hydrolytic enzymes. The cell wall of $C$. albicans has thus been a major area of investigation on candidal-host interactions mainly because of the role in adherence to its host (Levitz et al., 1987; Calderone et al., 1984; Maisch \& Calderone, 1981), and interactions with host immune systems (Calderone et al., 1988; Kuruganti et al., 1988). The plasma membrane, on the other hand, is of particular importance in homoeostatic control and susceptibility to antifungal agents (Shepherd, 1987).

The mechanism of transportation and secretion of $C$. albicans wall precursors from the cytoplasm to their

Abbreviations: IFA, indirect immunofluorescence assay; IEM, immunocolloidal gold electron microscopy; PBS, phosphate-buffered saline; $\mathrm{mAb}$, monoclonal antibody; GYEP, glucose yeast extract peptone; BSA, bovine serum albumin. destined wall location is unclear (Andaluz et al., 1986; Marriott, 1977; Rajasingham \& Cawson, 1984; Elorza et al., 1983). Although the biosynthesis of the wall of $C$. albicans is not fully understood, protoplast regeneration studies, electron microscopy and chemical determinations have revealed the chemical composition of the wall. These observations have confirmed the importance of the plasma membrane in the synthesis of cell wall layers (Duran et al., 1975; Tronchin et al., 1984; Marriott, 1977; Djaczenko \& Cassone, 1971; Korn \& Northcote, 1960; Takamiya et al., 1985; Elorza et al., 1983).

Further understanding of the role of the plasma membrane in cell wall biosynthesis requires detailed studies of critical cell wall epitopes which should be associated with the plasma membrane during various stages of wall synthesis. In spite of profound chemical, structural and functional differences between the cell membrane and wall of $C$. albicans, it has been suggested that certain epitopes may in fact be shared at various times in the cell cycle (Hopwood et al., 1986; Ollert \& Calderone, 1990). 
In the work described here, we determined the presence of an epitope found on the plasma membrane and also on the cell wall surface of $C$. albicans blastoconidia and germination tubes. The antigen distribution was observed at the ultrastructural level in cells fixed by the disparate techniques of traditional chemical methods and freeze-substitution. In addition, a chemical treatment that removed cell-surface antigen without disturbing the membrane was established for differential purification of the antigen from either location.

\section{Methods}

Organisms and culture conditions. Candida albicans strain 1 was used in all experiments unless indicated otherwise. This strain and other clinical isolates of $C$. albicans, Candida spp. and other fungi including Cryptococcus neoformans, Cr. albidus, Torulopsis glabrata, Rhodotorula and Saccharomyces cerevisiae were from the Montana State University mycology stock collection. Cultures were obtained from frozen stocks and grown on modified Sabouraud dextrose agar (Difco) slants. For most experiments, cells were transferred from slants and grown in glucose $(2 \%, w / v) /$ yeast extract $(0.3 \%, w / v) /$ peptone $(1 \%, w / v)$ broth (GYEP) at $37^{\circ} \mathrm{C}$ under constant aeration by rotation of flasks at 180 r.p.m. (Gyrotory incubator; New Brunswick Scientific). For immunoelectron microscopy (IEM) of intact yeast cells and preparation of spheroplasts, yeasts were grown in GYEP for $22-24 \mathrm{~h}$ at $37^{\circ} \mathrm{C}$ with aeration, reinoculated into fresh GYEP to a Klett value of 100 (KlettSummerson photoelectric colorimeter, no. 66 filter) and harvested in the exponential phase (Klett value 400). In some experiments, stationary-phase cells were harvested (Klett value 550). Two different media were used for induction of germination. In most experiments, hyphae were induced in a synthetic medium originally described by Lee et al. (1975) as modified by Sundstrom \& Kenny (1984) and referred to as modified Lee medium. Cells were grown in the modified medium without bovine serum albumin (BSA) for $48 \mathrm{~h}$ at $25^{\circ} \mathrm{C}$ to obtain yeastform cells and transferred to prewarmed medium at $37^{\circ} \mathrm{C}$ containing $1 \%(\mathrm{w} / \mathrm{v}) \mathrm{BSA}$ (ImmunoBiologicals) to promote germination. Cultures were incubated at $37^{\circ} \mathrm{C}$ and aerated by rotation at 180 r.p.m. An alternative medium was used in the IEM studies of germinating cells in which yeast-form cells were grown to stationary phase in GYEP at $37^{\circ} \mathrm{C}$, inoculated into GM-2 medium (Hazen \& Cutler, 1983) at $2 \times 10^{6}$ cells $\mathrm{ml}^{-1}$ and incubated at $37^{\circ} \mathrm{C}$ under aeration for hyphal induction. Germination was assessed by direct light microscopy and the cells were used if germination exceeded $90 \%$ by criteria defined previously (Hazen \& Cutler, 1979).

Spheroplasts and subcellular fractions. Spheroplasts were prepared following procedures described by others (Hudspeth et al., 1980; Wills et al., 1984) with slight modifications. Exponential-phase yeast cells were washed in $0.1 \mathrm{M}$-EDTA ( $\mathrm{pH} 7.5$, disodium salt, Sigma) suspended in $0.1 \mathrm{M}$-EDTA [ $2 \mathrm{ml}$ (g wet weight) ${ }^{-1}$ ] with $0.3 \mathrm{M}$ - $\beta$-mercaptoethanol (pH 9.0) and incubated at $24^{\circ} \mathrm{C}$ for $15 \mathrm{~min}$. Cells were pelleted by centrifugation at $2000 \mathrm{~g}$ for $10 \mathrm{~min}$ and suspended to the same concentration in $1.0 \mathrm{M}$-sorbitol/0.1 M-EDTA (pH 7.5). Zymolyase 20T (ICN) was added at 80 units per $g$ wet weight of yeast cells and incubated at $37^{\circ} \mathrm{C}$ for $60 \mathrm{~min}$ with frequent agitation. In some preparations for IEM, the $\beta$-mercaptoethanol-treated cells were incubated with Zymolyase for only $10 \mathrm{~min}$ to remove surface layers. The efficiency of spheroplast formation was determined by counting (haemocytometer) intact cells before and after lysis in $1 \%(w / v)$ SDS
(Sigma) as described by Glee et al. (1987). Spheroplasts were washed in $1 \mathrm{M}$-sorbitol/0.1 M-EDTA and either fixed for electron microscopy or processed as described below for mitochondrial fractions.

Subcellular fractions were prepared as described by Wills et al. (1984) for isolation of mitochondria. Spheroplasts, induced by treatment of yeast cells with Zymolyase for $60 \mathrm{~min}$ as above, were washed and suspended in $0.25 \mathrm{M}$-sucrose (Sigma), $1.0 \mathrm{~mm}$-EDTA and $5 \mathrm{~mm}$ Tris/ $\mathrm{HCl}$ (Sigma) $\mathrm{pH} 7.5$, and homogenized in a Dounce tissue homogenizer at $4{ }^{\circ} \mathrm{C}$. After removal of cell debris and intact cells by centrifugation at $3000 \mathrm{~g}$ for $10 \mathrm{~min}$, the supernatant material was centrifuged at $15000 \mathrm{~g}$ for $20 \mathrm{~min}$ to pellet the mitochondrial fraction. Fractions enriched for mitochondria obtained from continuous sucrose gradients $(25-50 \%, \mathrm{w} / \mathrm{v})$ run at $41000 \mathrm{~g}$ for $90 \mathrm{~min}$ (Wills et al., 1984) (SW $41 \mathrm{Ti}$ rotor, Beckman) were used for immunization of animals. This fraction contained mitochondria and other membranous vesicles as determined by electron microscopy.

Plasma membrane fraction. Plasma membrane fractions were obtained from yeast-form cells as described by Fuhrmann et al. (1974). Stationary-phase yeast cells were washed and suspended in an osmotic stabilizer (0.4 M-KCl, $20 \mathrm{mm-triethanolamine,} \mathrm{Sigma,} \mathrm{pH} \mathrm{7.0).} \mathrm{Cells}$ were broken in a heavy-walled centrifuge tube (Corex tubes, Corning Glass Works) by mixing with $0.45-0.5 \mathrm{~mm}$ glass beads on a vortex mixer (Hazen \& Cutler, 1982). The suspension was spun at $2000 \mathrm{~g}$ for 5 min to remove cell debris and the supernatant material was centrifuged at $5000 \mathrm{~g}$ for $10 \mathrm{~min}$ to pellet membranes. The crude membrane pellet was washed three times in the osmotic stabilizer, fractionated by sucrose density gradients $(10-60 \%)$ at $23500 \mathrm{~g}$ for $70 \mathrm{~min}$ and the resultant bands were collected.

Hybridoma and monoclonal antibody (mAb). Preliminary observations showed that mitochondria-rich fractions induced mice to produce antibodies which reacted with the mitochondrial fraction and with the cell surface of $C$. albicans. Thus, fractions enriched for mitochondria and other membranous vesicles, and hence referred to as the membranous fraction, were used for six weekly intravenous $0.1 \mathrm{ml}$ injections into BALB/cByJ mice. Lowry protein concentration was $4.6 \mathrm{mg} \mathrm{ml}^{-1}$. Three days after the last booster injection, mouse sera were checked for agglutinins against intact $C$. albicans blastoconidia, and splenocytes from agglutinin-positive animals were prepared for cell fusion with a non-secreting myeloma cell line. Detection of antibody produced by hybrids, cloning by limiting dilution and production of ascites in mice was done as previously described (Brawner \& Cutler, 1984).

Agglutination and ELISA. Qualitative agglutination tests were done on heat-killed yeast cells as described before (Brawner \& Cutler, 1984). ELISA tests (from either Bethesda Research Laboratories or Boehringer Mannheim Biochemicals) were used for detection and titrating of $\mathrm{mAb}$ in either culture fluid or ascites. Microtitre plates (96-well; Corning) were coated with $150 \mu$ l of yeast cell suspension $\left(2 \times 10^{6}\right.$ cells $\mathrm{ml}^{-1}$ ) in modified Lee medium at $37^{\circ} \mathrm{C}$ for germination. After $4 \mathrm{~h}$ incubation, the wells, now coated with germinating cells, were washed

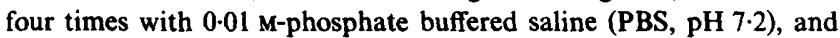
$100 \mu \mathrm{l}$ of appropriately diluted test fluid or negative control material were added and incubated at room temperature for $1 \mathrm{~h}$. ELISA detection of mouse mAb was done by following the manufacturer's instructions. In addition to negative controls as indicated above, fresh RPMI medium was used for detecting inappropriate binding of secondary antibody to the cells. An IgM mAb described previously as C6 was used as a positive control and identical results were obtained as before (Brawner \& Cutler, 1986).

Immunocolloidal gold electron microscopy (IEM). This technique was used to visualize the antigen expression on intact cells, spheroplasts and membranous fractions. Two procedures for fixation of samples were adopted for IEM. Samples were either chemically fixed in glutaralde- 
hyde $(0.5 \%, v / v) / o s m i u m$ tetroxide $(1 \%, w / v)$, and dehydrated through a graded ethanol series before embedding (Brawner \& Cutler, 1987), or freeze-fixed and substituted with anhydrous acetone as described by others (Hoch \& Howard, 1980, 1981; Hoch, 1986). In the latter procedure, a thin layer of yeast cells was very rapidly frozen at $-192{ }^{\circ} \mathrm{C}$ in a mixture of liquid propane and ethane, and the frozen samples were transferred to anhydrous acetone substitution fluid containing $2 \%$ osmium tetroxide and $0.05 \%$ uranyl acetate at $-80{ }^{\circ} \mathrm{C}$. Samples were dehydrated and fixed at $-80^{\circ} \mathrm{C}$ for $2-3 \mathrm{~d}$, and gradually brought up to room temperature $\left(22-24{ }^{\circ} \mathrm{C}\right)\left(2 \mathrm{~h}\right.$ at $-20^{\circ} \mathrm{C}, 2 \mathrm{~h}$ at $4{ }^{\circ} \mathrm{C}$ and then room temperature). This freeze-substitution method was used in fixing yeast cells and spheroplasts. Samples were washed three times in anhydrous acetone and embedded in Spurr's resin (Spurr, 1969) for thin sectioning. Thin sections on nickel grids were reacted with 10-times concentrated culture fluid from a cloned hybridoma cell line, blocked with $3 \%$ BSA, reacted with goat anti-mouse secondary antibody conjugated with colloidal gold $(10 \mathrm{~nm})(\mathrm{Janssen}$ Biotech), and finally contrast-stained with lead citrate and uranyl acetate.

Indirect immunofluorescence assay (IFA). The assay was modified from that described by Raff et al. (1976). Mycelium-form cells induced in modified Lee medium were harvested after different incubation times and fixed in $3 \%(\mathrm{v} / \mathrm{v})$ formaldehyde at $4{ }^{\circ} \mathrm{C}$ for $12 \mathrm{~h}$. Cells were washed and suspended in PBS, cytocentrifuged onto a glass slide and treated for $5 \mathrm{~min}$ at $4{ }^{\circ} \mathrm{C}$ in $5 \%(\mathrm{v} / \mathrm{v})$ acetic acid in $95 \%(\mathrm{v} / \mathrm{v})$ ethanol. Slides were washed in PBS and air dried before adding antibody. Undiluted ascites fluid containing the $\mathrm{mAb}$ or 10-times concentrated culture fluid from the chosen hybridoma clone was added to the fixed cells on the slides and incubated in a moist chamber for $15 \mathrm{~min}$ at $37^{\circ} \mathrm{C}$. Slides were washed by dipping in PBS several times at room temperature and air dried before adding fluorescein isothiocyanate (FITC)-conjugated goat anti-mouse immunoglobulin (Cappel) (diluted as suggested by the manufacturer). After incubation for $15 \mathrm{~min}$ at room temperature and washing in PBS, cells were examined with a fluorescence microscope (Nikon Episcopic-fluorescence microscope, type 104, equipped with a high-pressure mercury lamp $100 \mathrm{~W} / 2$ ). The same procedures were used for yeast and hyphal forms. Samples treated with normal mouse serum instead of primary antibody were incubated under the same conditions as a control for non-specific binding of secondary antibody.

Antigen extraction and partial characterization. The agglutininspecific antigen was solubilized from yeast cells by hot phenol extraction (Westphal \& Jann, 1965) as done previously on C. albicans (Cutler et al., 1972). The aqueous phase was collected, dialysed against deionized water, lyophilized and referred to as the phenol extract.

For characterization of the extracted antigen, the phenol extract was dissolved in PBS at a concentration of $5 \mathrm{mg} \mathrm{ml}^{-1}$ and boiled at $96^{\circ} \mathrm{C}$ for $10 \mathrm{~min}$. For enzymic treatment, antigen was solubilized at $5 \mathrm{mg} \mathrm{ml}^{-1}$ in $0.05 \mathrm{M}$-Tris/ $\mathrm{HCl}$ buffer $\mathrm{pH} 7.8$ with $5 \mathrm{mM}-\mathrm{CaCl}_{2}$ and the following enzymes were added: Pronase B (Calbiochem-Behring) 9 units $\mathrm{ml}^{-1}$, trypsin (Sigma, from bovine pancreas, type III) $2 \cdot 2$ units $\mathrm{ml}^{-1}$, and proteinase $\mathrm{K}$ (Sigma, type XI) 2.3 units $\mathrm{ml}^{-1}$. A standard substrate, azocoll (Sigma), was used at the same concentration $\left(5 \mathrm{mg} \mathrm{ml}^{-1}\right)$ as a positive control for each enzyme (Chavira et al., 1984). After incubation at $37^{\circ} \mathrm{C}$ for $2 \mathrm{~h}$ with agitation, solutions were either tested directly for antigen by reactivity against the $\mathrm{mAb}$ in ascitic fluid in an Ouchterlony double diffusion test or boiled prior to testing. Enzymes and heat-treated enzymes alone in the same buffer were used as controls for possible cross-reactions with the mAb in the double diffusion test.

Intact yeast cells were also treated with heat or proteolytic enzymes as above and examined for surface antigen activities by agglutination and IFA. C. albicans strain 1 grown in GYEP for $24 \mathrm{~h}$ was washed and suspended in the same buffer as described above at a concentration of $2 \times 10^{6}$ cells $\mathrm{ml}^{-1}$ and treated with various enzymes at $37^{\circ} \mathrm{C}$ for $2 \mathrm{~h}$.
Digestions of enzymes were terminated by boiling for $10 \mathrm{~min}$. Cells were washed in PBS and tested for the presence of antigen by IFA and agglutination. Untreated and heat-treated cells were used as controls.

Immunoelectrophoresis and other methods. Electrophoresis was done in $1 \%(w / v)$ low electroendosmosis agarose (Sigma) gel in different buffers at various pH values [ $25 \mathrm{~mm}$-citrate buffer, $\mathrm{pH} 5 \cdot 0 ; 10 \mathrm{mM}-\mathrm{PBS}$, pH 7.2; Tris/barbital buffer (Gelman Sciences) pH 8.8; and $50 \mathrm{~mm}$ Tris base pH 10.0]. Phenol extract in each buffer at $10 \mathrm{mg} \mathrm{ml}^{-1}$ was applied to a well and run for $3 \mathrm{~h}$ at $4 \mathrm{~V}(\mathrm{DC}) \mathrm{cm}^{-1}$. The $\mathrm{mAb}$ isotype was determined by Ouchterlony double diffusion in which goat antibodies specific for mouse light or heavy chain immunoglobulin determinants were used (Sigma).

Reliability of results. All of the experiments were done at least twice, on separate batches of cells each time. Photographs are representative of results obtained each time. Several approaches were used to confirm conclusions drawn from each; immunofluorescence was compared with IEM; IEM was performed on cells fixed by different methods; and results on whole cells were compared with subcellular fractions.

\section{Results}

$m A b$ preparation and characterization

Four stable hybridoma cell lines were obtained which reacted strongly against $C$. albicans strain 1 as determined by ELISA. One which was chosen for further investigation was cloned by limiting dilution, recloned and designated $\mathrm{mAb} 10 \mathrm{G}$. The ascites induced in BALB/cByJ mice by the cloned hybrid gave an ELISA titre of 2400 . The $\mathrm{mAb} 10 \mathrm{G}$ belongs to the IgM class with kappa light chains as determined by specific antisera (not shown).

\section{Expression of antigen on yeast cells}

Surface expression of the epitope recognized by $\mathrm{mAb}$ $10 \mathrm{G}$ (i.e. Ag 10G) was detected by agglutination and IFA of whole cells of $C$. albicans strain 1. Antigen distribution at the ultrastructural level was further investigated by IEM in cells fixed by two different procedures. Similar results were obtained from cells fixed by either glutaraldehyde or freeze-substitution. Ag 10G was usually found randomly distributed on the plasma membrane but had a patchy distribution on the wall surface (Fig. $1 a, b$ ). The ultrastructural preservation of plasma membranes, nuclei, walls and most cytoplasmic contents was improved by freeze-substitution techniques compared to traditional chemical fixation.

To investigate the strain and species specificity of expression of the antigen, other isolates of $C$. albicans as well as other Candida spp. and other fungal species were examined for surface expression of the antigen by the agglutination test. The following organisms gave positive agglutination reactions: all $15 C$. albicans clinical isolates and one isolate each of $C$. stellatoidea, $C$. 

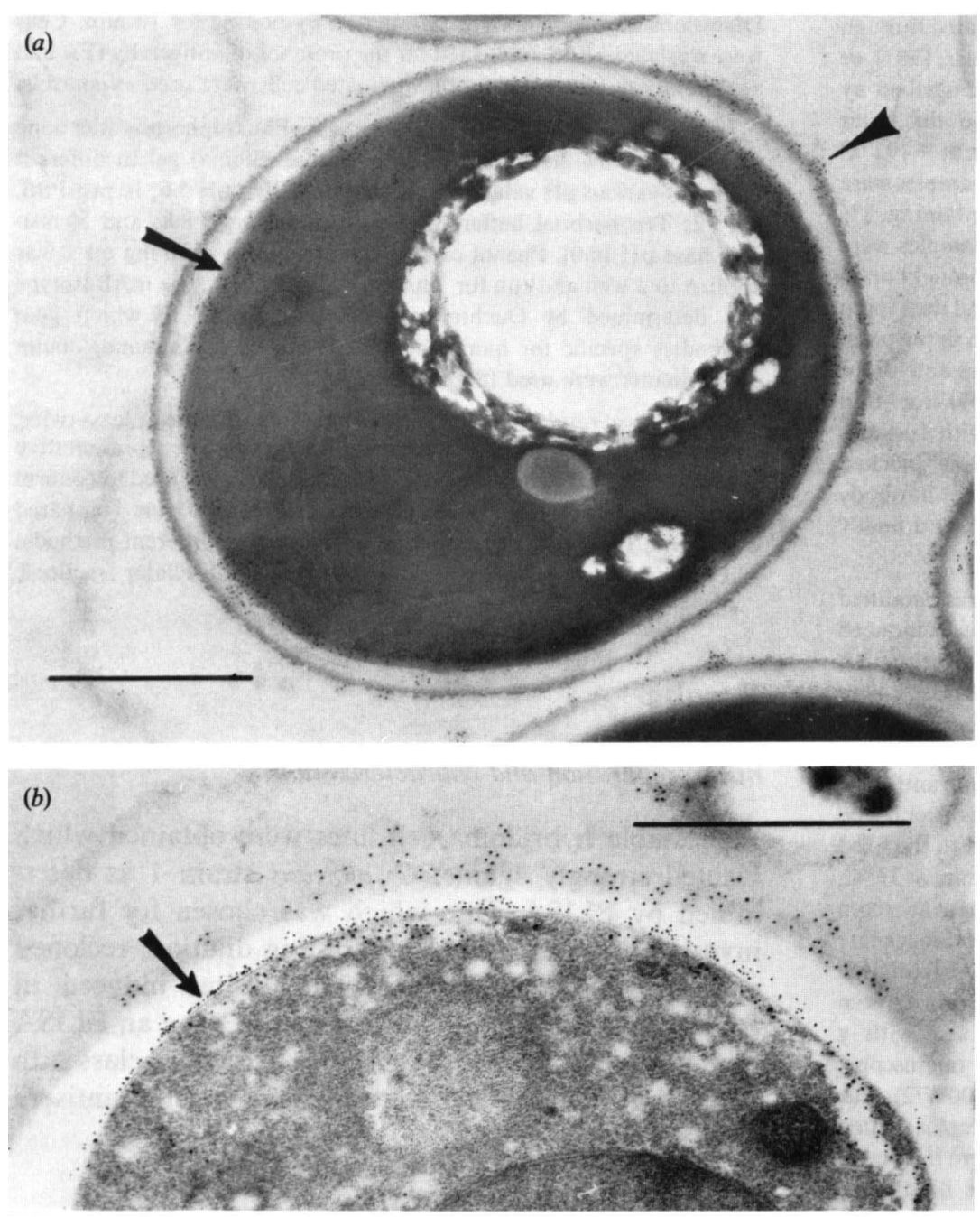

Fig. 1. Distribution of $10 \mathrm{G}$ epitope in exponential-phase cells fixed chemically at room temperature as compared to freeze-substituted cells. (a) Cells were fixed with glutaraldehyde and osmium tetroxide. Antigen was equally distributed near or on the plasma membrane (arrow) but unevenly on the cell wall surface (arrowhead). (b) Cells fixed by freeze-substitution show similar patterns of antigen distribution and better detail of membrane association of the antigen (arrow). Bars, $1 \mu \mathrm{m}$. tropicalis, $C$. lusitaniae and $C$. intermedia. No antigen was detectable by agglutination of other fungi, which included Candida utilis, C. krusei, Cryptococcus neoformans, Cr. albidus, Torulopsis glabrata, Rhodotorula spp. and Saccharomyces cerevisiae. Two of the agglutinationpositive isolates of C. albicans (strains 207 and 325) were examined by IEM and a similar pattern of antigen distribution was observed (data not shown).

\section{Expression of antigen on germinating cells}

Surface expression of antigen on hyphae of $C$. albicans was examined by IFA. Immunofluorescence of germinating cells was typically dense on the mother yeast cells throughout the incubation time. Antigen expression on the hyphal surface was not detectable for the first $2 \mathrm{~h}$ of incubation but became evident as germination proceeded (Fig. 2). These observations were subsequently confirmed by IEM.

Stationary-phase $C$. albicans cells grown in GYEP were transferred to GM-2 medium and allowed to germinate for up to $8 \mathrm{~h}$. After various incubation times, germinating cells were fixed with glutaraldehyde and prepared for IEM as described above. At time 0, stationary-phase cells had greater surface expression of antigen than exponential-phase cells (compare Fig. $3 a$ to Fig. 1). Throughout the entire incubation time allowed for hyphal development, antigen expression on parent cells was more dense on the cell wall surface than on the plasma membrane. The development of antigen on germ tubes was first observed after $2 \mathrm{~h}$ incubation. Unlike the distribution in parent cells, the antigen expressed on germ tubes was primarily in the subsurface area near or on the plasma membrane (Fig. $3 b$ ). At $6 \mathrm{~h}$, antigen became obvious on the cell surface and remained dense in the subsurface area (data not shown). Control experiments in which cells were treated with culture fluid of the non-secreting cell line did not show colloidal gold above background level ( $<10$ particles per cell) (not shown). 


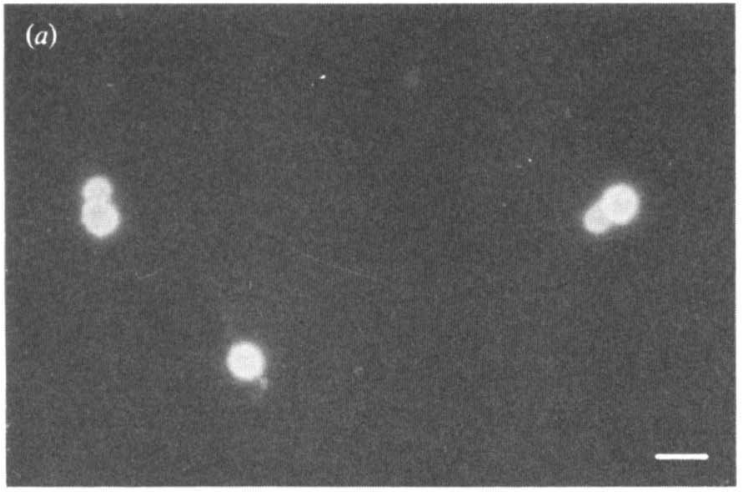

(b)

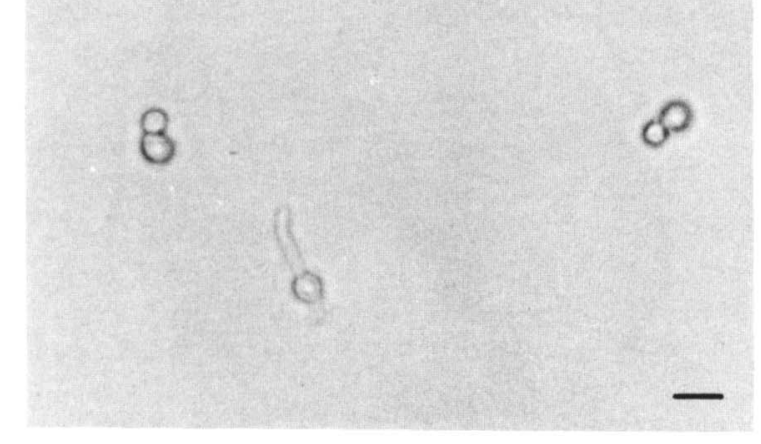

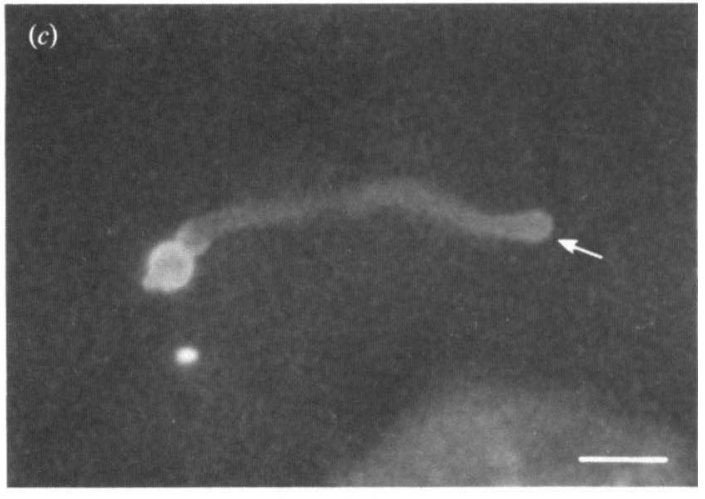

(d)

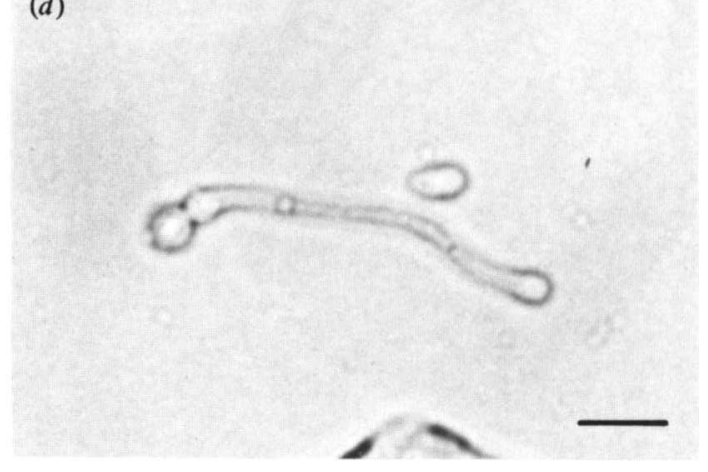

Fig. 2. Distribution of $10 \mathrm{G}$ epitope during germ tube development as determined by immunofluorescence. (a) At $2 \mathrm{~h}$ germination in modified Lee medium, no antigen was detectable on germ tubes; (b) bright field image. ( $c$ ) At $5 \mathrm{~h}$ development, antigen became evident along the entire surface of germ tubes and especially on the mother cell, the initial portion of the germ tube, and the growing apical region (arrow); $(d)$ bright-field image. Bars, $10 \mu \mathrm{m}$.

\section{Expression of antigen on spheroplasts}

Exponential-phase yeast cells were treated with $\beta$ mercaptoethanol and subjected to Zymolyase digestion for either 10 or $60 \mathrm{~min}$. The efficiency of spheroplast formation after Zymolyase digestion for $60 \mathrm{~min}$ was consistently over $90 \%$. Samples were freeze-substituted with acetone and prepared for IEM. In cells treated with $\beta$-mercaptoethanol and Zymolyase for $10 \mathrm{~min}$, antigen was removed from the surface but remained undisturbed on the plasma membrane. The fibrillar outer cell wall layer was also removed by this treatment (Fig. 4a). Organelles which had been released from lysed cells were occasionally observed. After $60 \mathrm{~min}$ incubation in Zymolyase, no cell wall was observed, yet antigen was still associated with the plasma membrane (Fig. $4 b$ ). The ultrastructural preservation of spheroplast organelles was generally improved compared with whole yeast cells.

\section{Expression of antigen on subcellular fractions}

To further confirm the association of the antigen with the plasma membrane, lysed spheroplasts and plasma membrane fractions were examined for the presence of antigen. Lysis of spheroplasts was induced by suspension in $0.5 \%$ glutaraldehyde without $1 \mathrm{M}$-sorbitol. In glutaraldehyde-fixed samples of spheroplasts, antigen was mostly found in vesicle structures but not on fragmented membranes (Fig. 5a). The vesicles apparently formed spontaneously during glutaraldehyde lysis of spheroplasts. The antigen was also not associated with the plasma membrane in membrane fractions (Fig. $5 b$ ). When lysed spheroplasts were freeze-fixed and substituted in acetone, the antigen was observed evenly distributed throughout the membranes (Fig. 5c).

Mitochondria-enriched fractions were also investigated using IEM in an attempt to explain their immunogenic nature. Fractions of mitochondria and membranes which co-purified with mitochondria were observed, but antigen was detectable only within single and multilamellar membrane vesicles (Fig. $5 d$ ).

\section{Characterization of $10 G$ antigen}

The phenol extract of $C$. albicans strain 1 was subjected to chemical and physical treatment and subsequently tested for antigen reactivity against $\mathrm{mAb} 10 \mathrm{G}$ in Ouchterlony double diffusion. Precipitin bands of variously treated 
(a)

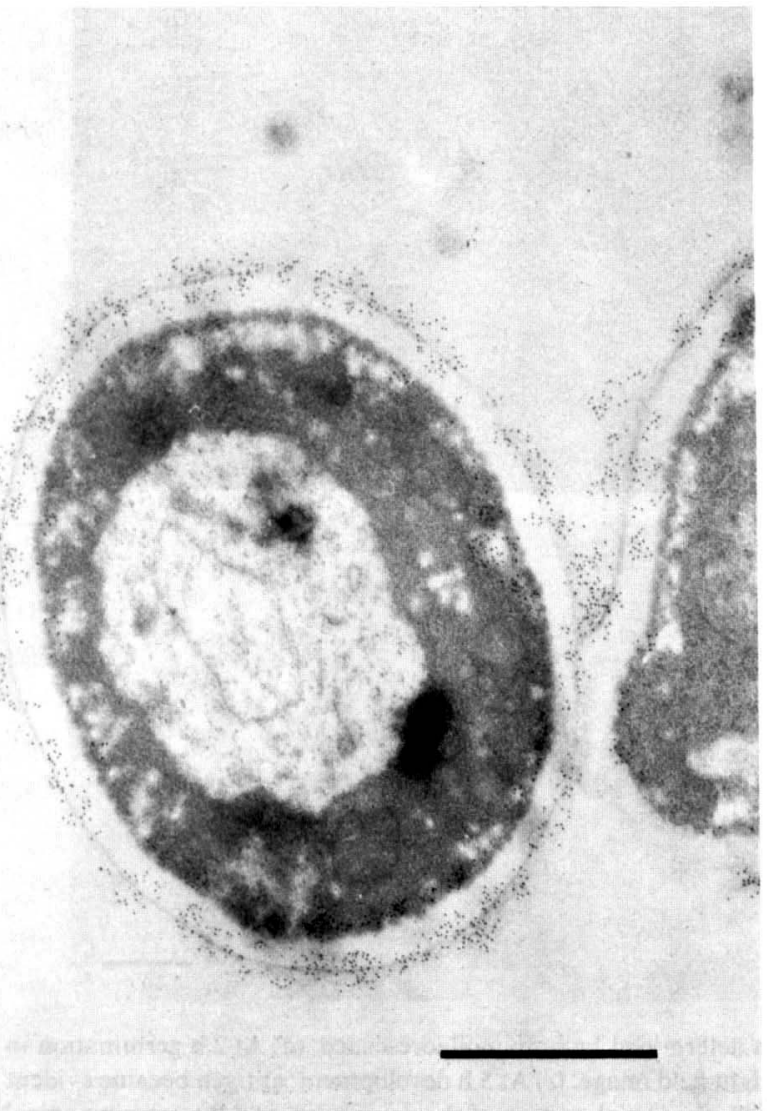

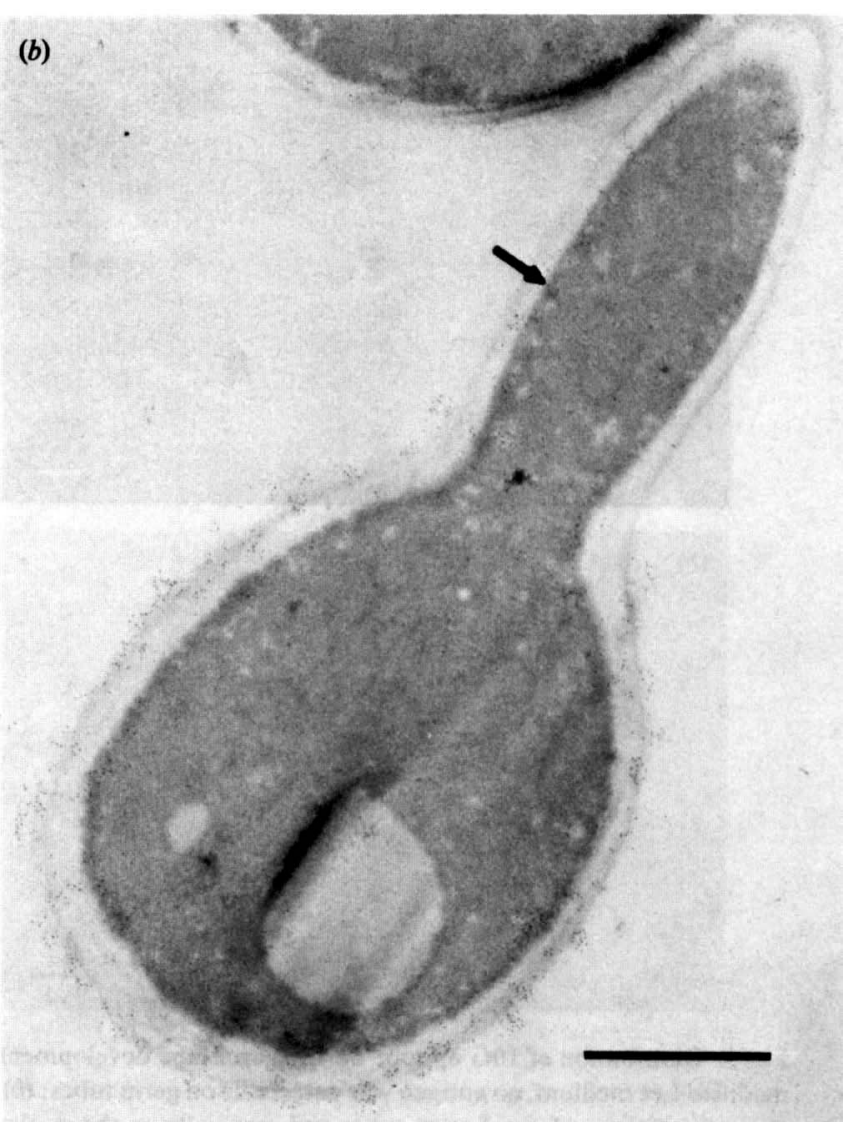

Fig. 3. Distribution of $10 \mathrm{G}$ epitope during germ tube development as determined by IEM. Stationary-phase yeasts were placed into germination conditions, harvested at various time intervals and fixed with glutaraldehyde and osmium tetroxide. (a) At time 0 , epitope expression was especially heavy on the cell wall surface. (b) After $2 \mathrm{~h}$ germination, antigen remained densely distributed on the mother cell wall surface, whereas on germ tubes it was primarily expressed in the cytoplasm near the cell membrane (arrow). Bars, $1 \mu \mathrm{m}$.

phenol extract showed identity with untreated material. The antigen reactivity was not altered by treatment with heat at $96^{\circ} \mathrm{C}$ for $10 \mathrm{~min}$ or with proteolytic enzymes (Pronase $\mathrm{B}$, trypsin, and proteinase $\mathrm{K}$ ).

Yeast cells grown in GYEP broth were also treated under the same conditions and screened for surface antigen activities by agglutination and IFA. Treated and untreated yeast cells showed the same degree of agglutination and fluorescence. Immunoelectrophoresis of the phenol extract produced a smeared precipitin band from the well of antigen toward the anode at all $\mathrm{pH}$ values tested (not shown).

\section{Discussion}

Among the many approaches to understanding cell wall structure and development of $C$. albicans, mAbs allow investigators to follow the expression of a particular determinant. In the present study, an IgM mAb, with kappa light chains, and designated 10G, was isolated which agglutinates $C$. albicans yeast cells. In addition to the cell surface location of the antigen to which $\mathrm{mAb}$ $10 \mathrm{G}$ is specific, the appearance of the immunodeterminant also on the plasma membrane was rigorously documented. These findings are not unique to a single strain of $C$. albicans because the same pattern of expression was found on other isolates of $C$. albicans. Our results indicate that $\mathrm{Ag} 10 \mathrm{G}$ is a common antigen in $C$. albicans and is also expressed in certain other Candida species (C. stellatoidea, $C$. intermedia, $C$. tropicalis and $C$. lusitaniae). The antigen is not expressed by $C$. utilis and C. krusei. In addition, the antigen was not detectable in other yeast genera. However, the absence of reactive epitope on the cell surface of C. utilis, C. krusei and other fungal genera as demonstrated by the agglutination test did not exclude the possibility of intracellular expression.

It has been suggested by other investigators, who used only immunofluorescence microscopy, that the same polysaccharide epitope recognized by a $\mathrm{mAb}$ was located on the cell surface and on the plasma membrane of $C$. albicans (Hopwood et al., 1986; Ollert \& Calderone, 

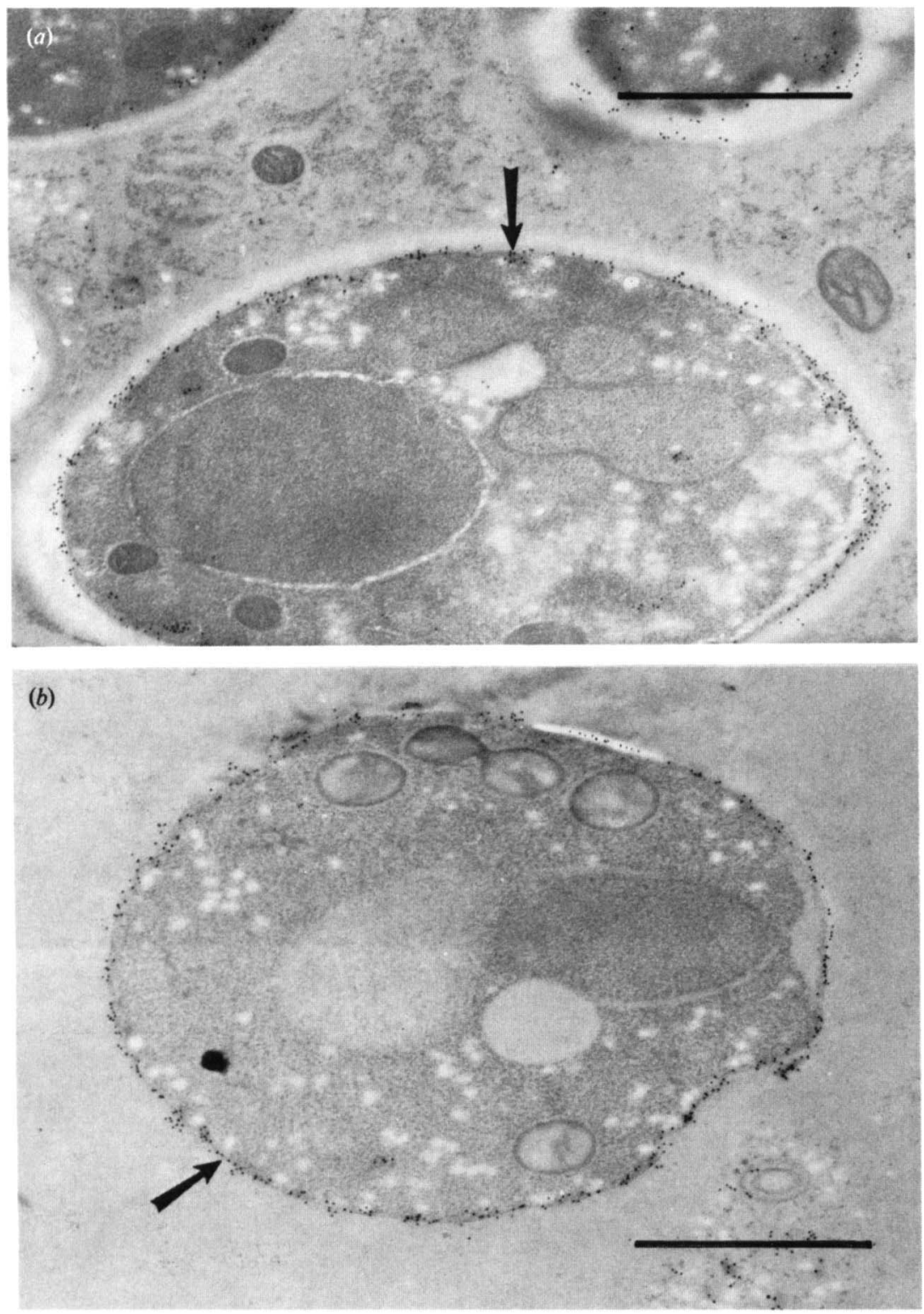

Fig. 4. Effect of Zymolyase treatment on the $10 \mathrm{G}$ antigen. Yeast cells were treated with Zymolyase for either $10 \mathrm{~min}(a)$ or $60 \mathrm{~min}(b)$, then samples were freeze-substituted and examined by IEM. The antigen was removed from the cell wall surface, while antigen on the plasma membrane was unaffected (arrows). Bars, $1 \mu \mathrm{m}$.
1990). Another group (Takamiya et al., 1985), who used ferritin-labelled antibody, localized a mannan antigen on the exterior cell wall surface as well as in the cytoplasm near the cytoplasmic membrane. The latter location was regarded as the site of mannan synthesis and it was suggested that the mannan antigens were transported from the cytoplasm via channel-like structures in the cell wall to the final deposits in the exterior cell wall layer. Similar speculation has been reported by others on cellular excretion of glycoproteins through the cell wall of $C$. albicans (Poulain et al., 1989). These workers intimated that antigen emergence at the cell surface may correspond to patches of the antigenic material in the fuzzy coat of the cell surface. Although channel-like structures were not observed in our studies, it may be hypothesized that the patchy distribution of the $10 \mathrm{G}$ antigen on the cell wall surface represents the site of antigen transportation. However, knowledge of the chemistry of the antigens at both locations is needed to determine whether the plasma membrane antigen is a cell wall precursor or is an unrelated, cross-reactive substance. Treatment of the cells with $\beta$-mercaptoethanol and Zymolyase selectively releases the antigen from the cell wall and will allow differential purification of the antigen from both locations for subsequent chemical comparisons.

Information on yeast wall synthesis comes primarily from studies on Saccharomyces cerevisiae (Tsai et al., 

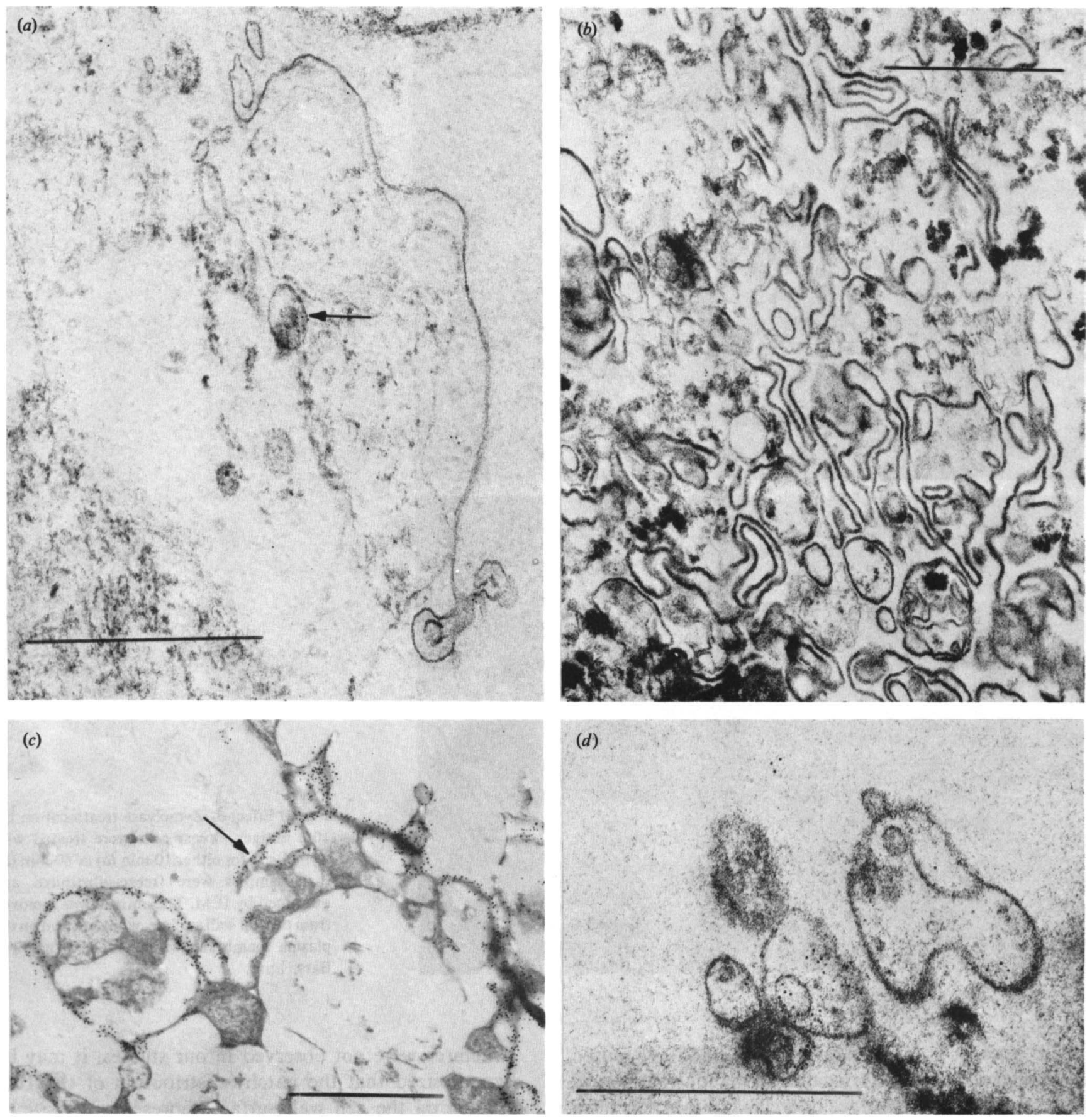

Fig. 5. Antigen $10 \mathrm{G}$ in membrane fractions. Lysed spheroplasts $(a)$ and membrane fractions $(b)$ fixed by glutaraldehyde. Antigen was not found on membrane fragments but was associated with vesicles (arrow). (c) Lysed spheroplasts fixed by freeze-substitution showing antigen association with the plasma membranes (arrow). (d) Mitochondria-enriched fractions in which variously sized vesicles comigrated and trapped the antigen during spontaneous vesicle formation. Bars, $1 \mu \mathrm{m}$.

1984; Novick \& Schekman, 1983; Novick et al., 1981). In C. albicans mannosylation reactions might occur at the plasma membrane level (Marriott, 1977), and enzymes associated with the cell wall matrix may modify the wall during growth and hyphal transformation (King et al., 1980; Barnes et al., 1983; Lehrer et al., 1986). In our observations, the early appearance of antigen on the membrane of germ tubes and later development on the surface suggests a growth-dependent expression of the antigen during hyphal development. In addition, the dense expression of the antigen corresponded with the growing apical region. We also noted that in yeast-form 
growth in GYEP, antigen expression was predominantly on the plasma membrane in exponential-phase cells and primarily on the cell surface of stationary-phase cells. Expression of cell-surface antigenic determinants may vary as a function of growth phase or morphological states (Brown \& Chaffin, 1981; Smail \& Jones, 1984; Sundstrom \& Kenny, 1984; Tronchin et al., 1984; Brawner \& Cutler, 1986) and our observations suggest that specific sites of antigen location may be related to structural modifications and/or cellular transportation of a cell wall-component during yeast growth and early stages of germination.

Ascribing antigen location at the ultrastructural level to specific cellular sites by results obtained from a single fixation procedure is open to criticism. Conventional chemical fixation using glutaraldehyde followed by osmium tetroxide may induce artifactual enlargement of dolipore septa in various basidiomycetes (Hoch \& Howard, 1981). Using freeze-substitution fixation, we obtained essentially identical patterns of antigen distribution as with glutaraldehyde fixation, which gives strong support for the cell wall/cell membrane locations of antigen 10G. In addition, freeze-substitution gave apparently better preservation of most of the intracellular organelles, plasma membranes and the fluffy outer layer of the cell wall of $C$. albicans. One limitation of the method was that only a low percentage of intact yeast cells showed acceptable preservation. The majority of spheroplasts, however, were well preserved. Hence, total or partial loss of cell wall layers may allow faster freezing and better penetration of embedding agents.

Comparison between the two fixation procedures on lysed spheroplasts suggests that although the antigen is associated with the plasma membrane, it is not well anchored. The presence of the antigen on plasma membranes fixed by freeze-substitution but not on those fixed by traditional means implies that the antigen becomes dissociated from the membrane during the many washing steps in the glutaraldehyde fixation procedure. A loose association between the antigen and the plasma membrane may explain the absence of antigen on membrane fractions (Fig. 5).

During preparation of mitochondria-enriched fractions, membrane vesicles spontaneously form (data not shown) and can trap antigen released from the cell membrane, as demonstrated by electron microscopy. Spontaneous vesicle formation and non-specific trapping of substances by the vesicles has also been observed by others during investigations on S. cerevisiae (Christensen \& Cirillo, 1972; Fuhrmann et al., 1974). In addition to explaining the specific immunogenicity of mitochondria-enriched fractions in our studies, these results indicate that vesicles may be artifactually created during cellular fractionation procedures. Furthermore, such vesicles may erroneously be thought to be associated with various cytoplasmic substances which were, in fact, passively trapped during vesicle formation.

The antigenic reactivity of either phenol extract or intact yeast cells was not altered after treatment with heat or proteolytic enzymes. These data, together with the behaviour of the phenol-extracted antigen in immunoelectrophoresis, indicate that antigen $10 \mathrm{G}$ is not a protein. Experiments to isolate and purify the epitope are now in progress, which will allow chemical comparisons between the cell-surface antigen and that of the plasma membrane.

We thank Pati Glee for assistance in preparation of mitochondriaenriched fractions, Diane Brawner for advice on hybridoma techniques and Susan Zaske for electron microscopic technical assistance.

This work was supported by a Public Health Service grant AI24912 from the National Institutes of Health.

\section{References}

Andaluz, E., Guillen, A. \& Larriba, G. (1986). Preliminary evidence for a glucan acceptor in the yeast Candida albicans. Biochemical Journal 240, 495-502.

Barnes, J. L., Osgood, R. W., Lee, J. C., King, R. D. \& Stein, J. H. (1983). Host-parasite interactions in the pathogenesis of experimental renal candidiasis. Laboratory Investigation 49, 460-467.

BRAWNER, D. L. \& CUTLER, J. E. (1984). Variability in expression of a cell surface determinant on Candida albicans as evidenced by an agglutinating monoclonal antibody. Infection and Immunity 43, 966972.

BraWNer, D. L. \& CUTLER, J. E. (1986). Ultrastructural and biochemical studies of two dynamically expressed cell surface determinants on Candida albicans. Infection and Immunity 51, 327336.

BraWNer, D. L. \& CutLer, J. E. (1987). Cell surface and intracellular expression of two Candida albicans antigens during in vitro and in vivo growth. Microbial Pathogenesis 2, 249-257.

Brown, L. A. \& Chaffin, W. L. (1981). Differential expression of cytoplasmic proteins during yeast bud and germ tube formation in Candida albicans. Canadian Journal of Microbiology 27, 580-585.

Calderone, R. A., Lehrer, N. \& Segal, E. (1984). Adherence of Candida albicans to buccal and vaginal epithelial cells: ultrastructural observations. Canadian Journal of Microbiology 30, 1001-1007.

Calderone, R. A., Linehan, L., Wadsworth, E. \& Sandberg, A. L. (1988). Identification of C3d receptors on Candida albicans. Infection and Immunity 56, 252-258.

Chavira, J., Burnett, T. J. \& Hageman, J. H. (1984). Assaying proteinases with azocoll. Analytical Biochemistry 136, 446-450.

Christensen, M. S. \& CiriLlo, V. P. (1972). Yeast membrane vesicles: isolation and general characteristics. Journal of Bacteriology 110 , 1190-1205.

CUTLER, J. E., Friedman, L. \& Milner, K. C. (1972). Biological and chemical characterization of toxic substances from Candida albicans. Infection and Immunity 6, 616-627.

DuaczenKo, W. \& Cassone, A. (1971). Visualization of new ultrastructural components in the cell wall of Candida albicans with fixatives containing TAPO. Journal of Cell Biology 52, 186-190.

Duran, A., Bowers, B. \& CABIB, E. (1975). Chitin synthetase zymogen is attached to the yeast plasma membrane. Proceedings of the National Academy of Sciences of the United States of America, 72, 3952-3955.

Elorza, M. V., Rico, H., Gozalbo, D. \& Sentandreu, R. (1983). Cell wall composition and protoplast regeneration in Candida albicans. Antonie van Leeuwenhoek 49, 457-469. 
Fuhrmann, G. F., Wehrli, E. \& Boehm, C. (1974). Preparation and identification of yeast plasma membrane vesicles. Biochimica et Biophysica Acta 363, 295-310.

Glee, P. M., Russell, P. J., Welsch, J. A., Pratt, J. C. \& Cutler, J. E. (1987). Methods for DNA extraction from Candida albicans. Analytical Biochemistry 164, 207-213.

HazeN, K. C. \& CUTLER, J. E. (1979). Autoregulation of germ tube formation by Candida albicans. Infection and Immunity 24, 661-666.

HAZEN, K. C. \& CUTLER, J. E. (1982). Optimal conditions for breaking medically important yeasts by an inexpensive and simple method. Mycopathologia 80, 113-116.

HAZEN, K. C. \& CUTLER, J. E. (1983). Effect of cobalt and morphogenic autoregulatory substance (MARS) on morphogenesis of Candida albicans. Experimental Mycology 7, 182-187.

HocH, H. C. (1986). Freeze-substitution of fungi. In Ultrastructure Techniques for Microorganisms, pp. 183-212. Edited by H. C. Aldrich, \& W. J. Todd. New York: Plenum Press.

Hoch, H. C. \& HowaRd, R. J. (1980). Ultrastructure of freezesubstituted hyphae of the basidiomycete Laetisaria arvalis. Protoplasma 103, 281-297.

HoCH, H. C. \& HowARD, R. J. (1981). Conventional chemical fixations induce artifactual swelling of dolipore septa. Experimental Mycology $5,167-172$.

Hopwood, V., Poulain, D., Fortier, B., Evans, G. \& Vernes, A. (1986). A monoclonal antibody to a cell wall component of Candida albicans. Infection and Immunity 54, 222-227.

Hudspeth, M. E. S., Shumard, D. S., Tatti, K. M. \& Grossman, L. I. (1980). Rapid purification of yeast mitochondrial DNA in high yield. Biochimica et Biophysica Acta 610, 221-228.

KING, R. D., LEE, J. C. \& MoRrIS, A. L. (1980). Adherence of Candida albicans and other Candida species to mucosal epithelial cells. Infection and Immunity 27, 667-674.

KorN, E. D. \& NorthCote, D. H. (1960). Physical and chemical properties of polysaccharides and glycoproteins of the yeast-cell wall. Biochemical Journal 75, 12-17.

Kuruganti, U., Henderson, L. A., Garner, R. E., Asofsky, R., BAKer, P. J. \& Domer, J. E. (1988). Nonspecific and Candidaspecific immune responses in mice suppressed by chronic administration of anti- $\mu$. Journal of Leukocyte Biology 44, 422-433.

Lee, K. L., BuCkley, H. R. \& CAMPBell, C. C. (1975). An amino acid liquid synthetic medium for the development of mycelial and yeast forms of Candida albicans. Sabouraudia 13, 148-153.

Lehrer, N., Segal, E., Cihlar, R. L. \& Calderone, R. A. (1986). Pathogenesis of vaginal candidiasis: studies with a mutant which has reduced ability to adhere in vitro. Journal of Medical and Veterinary Mycology 24, 127-131.

Levitz, S. M., Lyman, C. A., Murata, T., Sullivan, J. A., Mandell, G. L. \& DiAmond, R. D. (1987). Cytosolic calcium changes in individual neutrophils stimulated by opsonized and unopsonized Candida albicans hyphae. Infection and Immunity 55, 2783-2788.
Maisch, P. A. \& Calderone, R. A. (1981). Role of surface mannan in the adherence of Candida albicans to fibrin-platelet clots formed in vitro. Infection and Immunity 32, 92-97.

MARRIOTT, M. S. (1977). Mannan-protein location and biosynthesis in plasma membranes from the yeast form of Candida albicans. Journal of General Microbiology 103, 51-59.

Novick, P. \& SCheKman, R. (1983). Export of major cell surface proteins is blocked in yeast secretory mutants. Journal of Cell Biology 96, 541-547.

Novick, P., Ferro, S. \& Schekman, R. (1981). Order of events in the yeast secretory pathway. Cell 25, 461-469.

Ollert, M. W. \& CALDERone, R. A. (1990). A monoclonal antibody that defines a surface antigen on Candida albicans hyphae crossreacts with yeast cell protoplasts. Infection and Immunity 58, 625-631.

Poulain, D., Cailliez, J. C . \& DubremeTZ, J. F. (1989). Secretion of glycoproteins through the cell wall of Candida albicans. European Journal of Cell Biology 50, 94-99.

RafF, M. C., Megson, M., Owen, J. J. T. \& COOPER, M. D. (1976). Early production of intracellular IgM by B-lymphocyte precursors in mouse. Nature, London 259, 224-226.

Rajasingham, K. C. \& CAwson, R. A. (1984). Plasmalemmasomes and lomasomes in Candida albicans. Cytobios 40, 21-25.

SHEPHERD, M. G. (1987). Cell envelope of Candida albicans. CRC Critical Reviews in Microbiology 15, 7-25.

SMaIL, E. H. \& JoNES, J. M. (1984). Demonstration and solubilization of antigens expressed primarily on the surfaces of Candida albicans germ tubes. Infection and Immunity 45, 74-81.

SPURR, A. R. (1969). A low viscosity epoxy resin embedding medium for electron microscopy. Journal of Ultrastructure Research 26, 31-38.

Sundstrom, P. M. \& KenNY, G. E. (1984). Characterization of antigens specific to the surface of germ tubes of Candida albicans by immunofluorescence. Infection and Immunity 43, 850-855.

Takamiya, H., Vogt, A., Batsford, S., Kuttin, E. S. \& Muller, J. (1985). Further studies on the immunoelectronmicroscopic localization of polysaccharide antigen on ultra-thin sections of Candida albicans. Mykosen 28, 17-32.

Tronchin, G., Vernes, A. \& Poulain, D. (1984). Cytochemical and ultrastructural studies of Candida albicans. III. Evidence for modification of the cell wall coat during adherence to human buccal epithelial cells. Archives of Microbiology 139, 221-224.

Tsai, P.-K., Ballou, L., Esmon, B., Shekman, R. \& Ballou, C. E. (1984). Isolation of glucose-containing high-mannose glycoprotein core oligosaccharides. Proceedings of the National Academy of Sciences of the United States of America, 81, 6340-6343.

WESTPHAL, O. \& JANN, K. (1965). Bacterial lipopolysaccharides Extraction with phenol-water and further applications of the procedure. Methods in Carbohydrate Chemistry 5, 83-91.

Wills, J. W., Lasker, B. A., Sirotkin, K. \& Riggsby, W. S. (1984). Repetitive DNA of Candida albicans: nuclear and mitochondrial components. Journal of Bacteriology 157, 918-924. 